\title{
ROOT CANAL FILLING WITH NEOMTA PLUS IN SECOND PRIMARY MOLAR TEETH WITH MISSING SUCCESSOR: TWENTY-FOUR MONTHS OF FOLLOW-UP
}

\begin{abstract}
Hypodontia of the mandibular second premolar teeth is one of the most frequent anomalies of tooth development, which reveals a unique hardship for clinicians. Retaining the primary second molars helps to maintain arch integrity until facial growth is complete. This case series investigates the potential improvement and longevity of retained primary mandibular second molars obturation of the root canal system using a mineral trioxide aggregate when successors are missing. Neo MTA Plus (Avalon Biomed Inc, Bradenton, FL) recently introduced calcium silicate-based cement that may have some potential as a root canal obturating material. Nevertheless, no study using Neo MTA Plus as a root canal filling material was found in the literature. Five female patients with a decayed, necrotic second primary molar tooth without a successor were selected and performed a root canal treatment with Neo MTA Plus. Patients were scheduled for clinical and radiographic evaluation at $6,12,18$, and 24 months. They were followed up for twenty-four months. According to the present study, it can be concluded that NeoMTA Plus may be a proper material for use in the root canal treatment of primary molars with a missing successor.
\end{abstract}

Keywords: Root Canal Filling, Neo MTA Plus, Pulpectomy, Primary Molar, Tooth Agenesis.

\section{Highlights of the study}

- The complex anatomical irregularities of the primary molars root canal system present technical difficulties for the complete cleaning and obturation of the root canal.

- It was concluded that NeoMTA Plus might be a suitable obturation material in primary molars' pulpectomy with missing successors, while treatment with guttapercha may reveal some difficulties.

- NeoMTA Plus was not used as a root filling material in previous studies. This case series is the first study that used NeoMTA Plus as a root filling material with successful clinical results.

\author{
Özgür Doğan ${ }^{1}$ \\ Edanur Gökçe Meydan ${ }^{1}$ \\ Suat Serhan Altıntepe Doğan ${ }^{2}$ \\ (D) *Nebi Cansın Karakan ${ }^{2}$ \\ iD İsmail Haktan Çelik ${ }^{1}$
}

\footnotetext{
${ }^{1}$ Department of Pediatric Dentistry, Faculty of Dentistry, Afyonkarahisar Health Science University, Afyonkarahisar, Turkey.

2 Department of Periodontology, Faculty of Dentistry, Afyonkarahisar health science university, Afyonkarahisar, Turkey.
} 


\section{INTRODUCTION}

Hypodontia, one of the most common anomalies of dentition, is defined as the congenital absence or agenesis of one or more primary or permanent teeth, excluding the third molars. ${ }^{1}$ Agenesis of the mandibular second premolar teeth is one of the most frequent anomalies of tooth development. It reveals a hardship to clinicians in terms of diagnosis and management. ${ }^{2}$ Several studies in different populations have reported these teeth to account for more than $40 \%$ of all hypodontia cases, making mandibular second premolars the second most common congenitally missing teeth after the third molars. ${ }^{2}$ The second premolar agenesis prevalence was reported as $2.4 \%$ to $4.3 \% .^{3}$

In cases of primary molars without a permanent successor, they remain in place beyond the time of regular exfoliation. Treatment preferences for these over-retention cases comprise preservation of the primary molar as a long-term temporary resolution until the completion of facial growth or extraction of the primary molar. Space closure includes various methods and depends on patient-related conditions such as age, occlusion, and the primary molar tooth and alveolar bone condition. ${ }^{3,4}$ These teeth frequently exhibit a tendency to caries owing to prolonged retention in the mouth. Furthermore these teeth include a thin enamel layer than permanent teeth. Furthermore, owing to their large pulp horns, pulpal involvement is frequently observed. ${ }^{1}$

Primary teeth are significantly different from permanent teeth regarding the cellular content of their undifferentiated mesenchymal stem cells. They contain an abundant supply of stem cells in their dental pulp compared to permanent teeth. Mesenchymal cells may give rise to odontoclastic cells in response to either the caries process or the pulp-capping material, resulting in the exaggerated inflammatory response and, consequently, the internal resorption in the primary teeth. Pathologic root resorption is the most common cause of premature tooth loss in primary dentition. ${ }^{5,6}$ If the treatment preference is to preserve a primary molar with deep caries lesion including pulpal invasion, it includes a pulpotomy or root canal treatment. Zinc oxide eugenol and calcium hydroxide with iodoform pastes are resorbable when used in pulpectomies. They demonstrate resorption rates similar to the physiologic root resorption rates of primary molars with successors. However, their use might not be ideal in the case of extremely slow root resorption of necrotic primary molars without successors. $^{7}$

If pulpectomy is essential, filling the root canal with gutta-percha is the standard treatment method and the treatment of permanent teeth. ${ }^{8}$ non-resorbable root canal filling material application aims to keep the primary molar in dentition as long as possible without root resorption to maintain adequate bone, which has a crucial role in an implant surgery requirement after the patient's bone development comes up to an end. ${ }^{3,4}$ Nevertheless, anatomical disorders such as curved fragile primary molar roots with complex internal anatomy may prevent complete removal of the necrotic tissue. That would eventually result in a suboptimal root filling in the root canal systems of primary teeth compared to permanent teeth. As a result, performing root filling with gutta-percha may be more difficult. ${ }^{9}$

Modern pediatric dentistry seeks novel methods for the regeneration of remaining dental tissues to preserve primary teeth and maintain their developmental, esthetic, and functional capabilities. For this purpose, biocompatible materials such as bone morphogenetic proteins, osteogenic protein-1, demineralized dentin, and mineral trioxide aggregate have previously been studied. $^{10}$ More recently, mineral trioxide aggregate (MTA) has been recommended for root canal obturation in retained primary teeth due to its capacity to provide a biocompatible material. It has been revealed that MTA has excellent sealing ability, and it stimulates hard-tissue healing in lateral root perforations, internal resorption, furcal perforations, and as a root-end filling. ${ }^{10}$ MTA is a dental material used extensively for vital pulp therapies (VPT), protecting scaffolds during regenerative endodontic procedures, apical barriers in teeth with necrotic pulps and open 
apices, perforation repairs, as well as root canal filling and root-end filling during surgical endodontics. ${ }^{11}$ MTA has been used for many other applications, including primary teeth pulp capping and pulpotomy. ${ }^{12}$ Several case reports have been published describing the use of MTA as an alternative root canal filling material for primary teeth without successors. ${ }^{13}$

However, long-setting, tooth discolouration, high cost, and complex handling characteristics have emerged as potential drawbacks. ${ }^{10}$ Recently, new bioactive materials have been introduced and one of them was NeoMTA Plus. This silicatebased hydraulic tricalcium contains tantalum oxide as a radiopacifying agent in place of bismuth oxide, thus avoiding discolouration and can enhance the mineralization potential by inducing differentiation into mineralsecreting cells. ${ }^{14}$ Furthermore, it has been reported that NeoMTA Plus has a capacity to release calcium, to prevent bacterial leakage, to reveal adequate radio-opacity, and it has good sealing ability. Thanks to these features of MTA, it can be used as an endodontic sealer or cement repair. ${ }^{15}$

\section{METHODS}

\section{Case Series}

\section{Preoperative Findings}

In this study, following orthodontic consultations, only patients with minimal crowding $(1-3 \mathrm{~mm})$ or perfect alignment according to the Little's Irregularity Index in the lower arch and those with no class II molar relationship, mandibular retrusion, and other orthodontic anomalies were included. Patients with infraocclusion and ankylosis were also excluded. Moreover, patients were followed up periodically for infraocclusion and ankylosis since either infraocclusion or ankylosis greater than $1 \mathrm{~mm}$ would indicate extraction. Infraocclusion or ankylosis would affect bone height and require bone grafting for any future implant restoration. However, infraocclusion or ankylosis was not observed among the participants.

A total of five healthy patients were referred to the Department of Pediatric Dentistry of the Afyonkarahisar Health Science University Faculty of Dentistry in Afyonkarahisar, Turkey, for endodontic and restorative management of primary mandibular second molars with missing permanent successors. All affected teeth presented with deep carious lesions or failed restorations and sinus tracts in the absence of sensitivity to percussion and tenderness to palpation. Following consultations with the department of orthodontics, a treatment plan involving endodontic and restorative treatment of the molars was made to prevent malocclusion and maintain the existing alveolar dimensions. Molars had healthy occlusal relationships, with no sign of ankylosis or infraocclusion. A radiographic examination revealed periradicular and interradicular radiolucency without internal or external root resorptions and approved the congenital absence of second premolars.

\section{Treatment Protocol}

All molars received the same two-visit root canal protocol. Pulpectomies were performed as described below. At the first visit, an inferior alveolar nerve block was performed by administering 2\% lidocaine with 1:100 000 adrenaline (Astra Pharmaceutical Products, Westboro, Mass., USA); caries was removed using a tungsten-carbide bur in a slow speed handpiece was used to excavate caries after using a water-cooled aerator. Following the removal of the coronal pulp, the diagnosis of pulpal status was determined. If the radicular pulp presented continuous bleeding, the diagnosis was "irreversible pulpitis"; however, if no pulp tissue remained when the pulp chamber was accessed or in cases suppuration or purulence presented, the diagnosis was "pulp necrosis." The working length was determined using a size 15 sterile Kfile to $2 \mathrm{~mm}$ short of the radiographic apex. Intracanal tissue was extirpated using a barbed broach (Dentsply/Maillefer, Ballaigues, Switzerland), and the canals were prepared with Protaper Gold (PTG, Dentsply Maillefer, Ballaigues, Switzerland) until a master file size of F2 File was reached. Each root canal orifice was irrigated between instruments with $2 \mathrm{~mL}$ of $5.25 \%$ sodium hypochlorite $(\mathrm{NaOCl})$ (Promida 5.25\%, Promida, Eskişehir, Turkey) using a 27-gauge dental irrigation needle with round close end \& round 
open. It was positioned approximately $2-3 \mathrm{~mm}$ below the root canal orifice and final irrigation with $5 \mathrm{~mL}$ of sterile saline was performed. The canals were dried with pre-measured paper points up to $2 \mathrm{~mm}$ from the root apices and were dressed with non-setting calcium hydroxide for one week (Metapaste, Meta Biomed, Chungbuk, Korea).

At the second visit, after the removal of calcium hydroxide, NeoMTA Plus (Avalon Biomed, Bradenton, FL, USA) under aseptic conditions, NeoMTA Plus were mixed according to the manufacturers' instructions, dispense one scoop ( 1 gr) of NeoMTA Plus powder on a glass slab done one drop of MTA Plus Gel as a streak $0.5-0.75$ inch long next to the powder. After that, a putty-like consistency material was placed in the canal via MTA carrier (Sybro Endo, Orange, CA, USA) and compacted using endodontic pluggers. The MTA was allowed to set entirely by placing a cotton pellet moistened with sterile water inside the pulp chamber for 15 minutes and sealing the access cavity with glass ionomer cement (Fuji IX, GC, Tokyo, Japan). Furthermore, the cavities were permanently restored with composite resin incrementally and final restoration was done by stainless steel crown (Clearfil Majesty Posterior A2, Kuraray, Osaka, Japan) as a final restoration (Figure).

Case 1
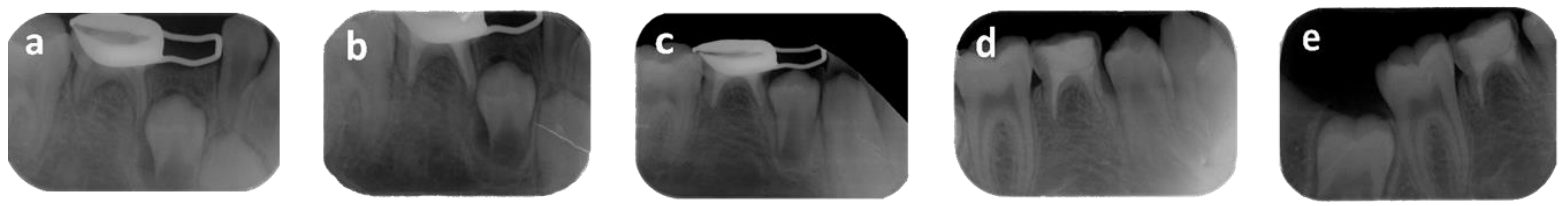

Case 2
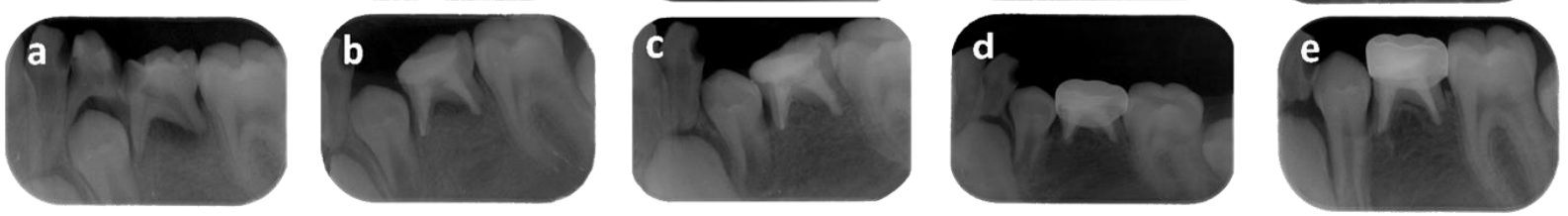

Case 3
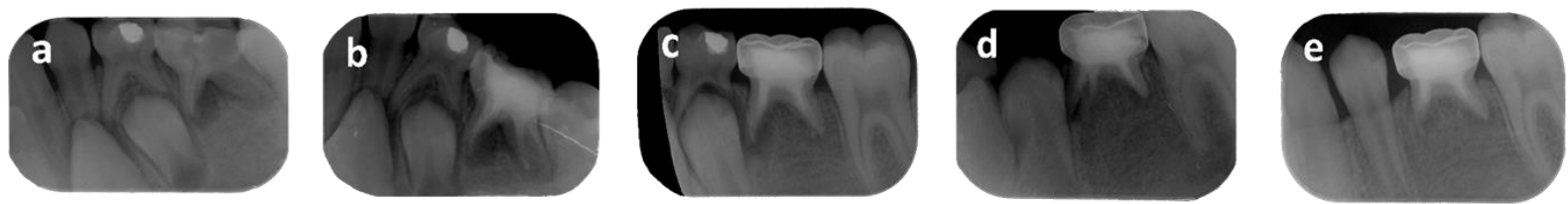

Case 4
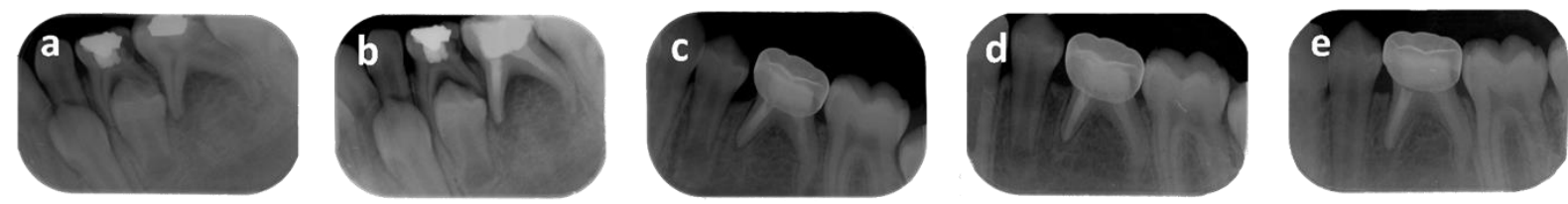

Case 5
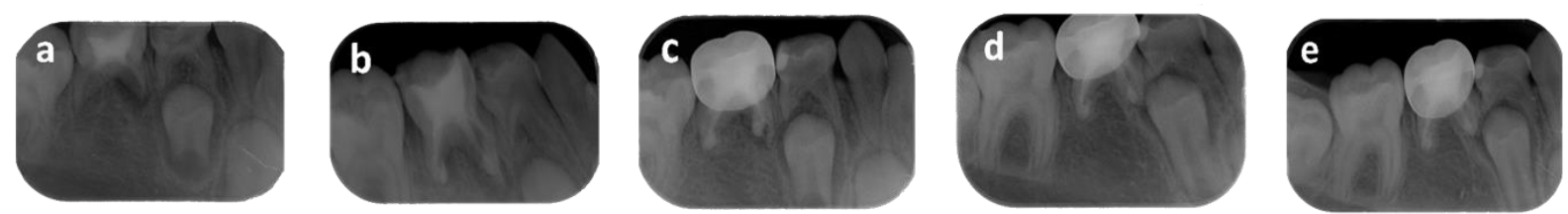

Figure: Root Canal Filling with NeoMTA a: Preoperative radiograph of the tooth. b: 6 months of follow-up. c: 12 months of follow-up. d: 18 months of follow-up. e: 24 months of follow-up

\section{DISCUSSION}

The treatment preference for agenesis of the mandibular second premolar teeth depends on the patients' specific conditions and the second primary molar tooth. In adult patients, treatment options include single-tooth implants, autotransplantation, and prosthetic restoration. Long-term follow-up studies in pediatric patients have provided evidence that properly-maintained primary molars without successors remain until middle age in some cases. ${ }^{3,4}$ Mandibular second premolar agenesis treatment preferences should merely be considered after orthodontic consultation. ${ }^{7}$ Early removal of the primary second molar initiates a series of changes, including a reduction in arch length, an inclination of adjacent teeth, alveolar bone resorption, extrusion of the antagonist's tooth, and alterations in tongue posture, which may all be challenging to 
treat orthodontically. ${ }^{3,6}$ However, it is recommended to maintain the second primary molar in cases of class II occlusion, mandibular retrusion, polydiastema and non-crowded dental arches. ${ }^{7}$ While the latter option poses the risks of infraocclusion and ankylosis if the patient is followed up closely, retaining primary second molars in a restorable condition can be the best space and alveolar bone maintainers, representing a semi-permanent solution in non-crowded dental arches until alveolar development is complete. After this stage, implant therapy can be performed. ${ }^{3}$

Two features of root canal filling materials that may dramatically affect treatment prognosis are sealing ability and antibacterial effectiveness, considering that MTA has been revealed to possess superior biocompatibility and sealing ability. When used for repair of perforations, VPT, root-end fillings, and when used as an apical plugin, many laboratories, animal and clinical studies, including those examining bacteria and endotoxin leakage. ${ }^{10,16}$ MTA has been revealed to possess antibacterial features useful against bacteria comprising Enterococcus faecalis, suggesting that any bacteria remaining in the ramifications of the root canal system may have been eliminated or at least dramatically reduced. ${ }^{16}$ Tunc and Bayrak ${ }^{13}$ emphasized that white MTA treatment in primary molar teeth has been successful in the 3 years. Teeth with irreversible pulpitis represent a significantly higher treatment success rate than teeth with necrotic pulp. ${ }^{17} \mathrm{~A}$ two-stage treatment method with the use of calcium hydroxide as an inter-appointment dressing has been proposed as a standard for infected teeth in order to maximize bacterial reduction and enhance treatment outcomes. ${ }^{18}$

Moreover, in histological studies, it has been emphasized that using an antibacterial agent between sessions in teeth with apical periodontitis showed better outcomes. The two-stage treatment method with calcium hydroxide dressing was used in all the cases in this study. No significant difference in success rates was found between one and two-stage treatment methods. ${ }^{19}$
If a hermetic seal cannot be maintained through obturation, tissue fluids may enter the canal and provide additional nutrition to any remaining bacteria. ${ }^{20}$ Application of stainless steel crowns (SSC) has been recommended after the pulpal treatment of primary teeth. ${ }^{8}$ However, in this study, four of the treated teeth were restored with composite resins and SSCs. (one of the teeth had a fixed space maintainer, previously).

This study had some limitations. We did not use rubber-dam clamps for all patients because some could not tolerate the rubber-dam clamps pressure and latex frame. Additionally, we could not use SSC to increase the survival rate and bite blocks in some patients in order to achieve standardized radiographs for endodontic treatment follow-up. Although the use of bite blocks is frequent, this method was not an option in the present study because the study subjects were in the mixed dentition stage, characterized by alterations in occlusal development. ${ }^{20}$

\section{CONCLUSIONS}

The good results obtained with NeoMTA Plus can be attributed to the material's sealing ability, antimicrobial and anti-inflammatory properties. In this study, successful results was observed in the cases treated with NeoMTA Plus. Within the limitations of this study, it can be concluded that NeoMTA Plus can be recommended for use in the root canal treatment of primary second molars without successors based on radiographic evidence.

\section{$\ddot{O} Z$}

Mandibular ikinci premolarda görülen hipodonti, diş gelişimindeki en sı görülen anomalilerden biridir ve klinisyenler için nadirde görülse zorluklar ortaya çılkarır. Süt ikinci azıların ă̆ızda tutularak idame edilmesi, yüz gelişimi tamamlanana kadar ark bütünlüğ̈̈nün korunmasına yardımcl olur. Bu olgu serisinde, yerine gelecek daimi dişin olmadiğl ve kök kanal sistemlerinin mineral trioksit agregat (MTA) ile kapatıldiğ d durumlarda, süt mandibular ikinci molarların potansiyel gelişim ve ömürleri incelendi. NeoMTA Plus (Avalon Biomed Inc, Bradenton, FL) yeni tanitılan, kök kanal dolum materyali olarak kullanilabilen kalsiyum silikat bazl bir simandir. Bununla birlikte literatürde NeoMTA Plus'ın kök kanalı 
dolum materyali olarak kullanıldığın belirten herhangi bir çalışma bulunmamaktadır. Altında daimi diş germi olmayan, çürük veya nekrotik süt ikinci molara sahip beş hasta seçilip, bu hastalara NeoMTA Plus ile kök kanal tedavisi uyguland. Hastalar klinik ve radyografik değerlendirmeler için $6,12,18$ ve 24 ay sonra kontrol seanslarına çağırıldl. Hastalar 24 ay süresince takip edildi. Günümüzdeki çallşmaya göre NeoMTA Plus'ın, altında daimi diş olmayan süt molarların kök kanal tedavisinde kullanılmak üzere uygun bir materyal olduğu sonucuna varılmuşttr. Anahtar kelimeler: Kök Kanal Dolumu, NeoMTA Plus, Pulpektomi, Süt Molar, Diş Agenezisi.

\section{REFERENCES}

1. Meaney S, Anweigi L, Ziada H, Allen F. The impact of hypodontia: A qualitative study on the experiences of patients. Eur J Orthod 2012;34:547-552.

2. Polder BJ, Van't Hof MA, Van der Linden FPGM, Kuijpers-Jagtman AM. A meta-analysis of the prevalence of dental agenesis of permanent teeth. Community Dent Oral Epidemiol 2004;32:217-226.

3. Bjerklin $\mathrm{K}, \mathrm{Al}-\mathrm{Najjar} \mathrm{M}$, Kårestedt $\mathrm{H}$, Andrén $\mathrm{A}$. Agenesis of mandibular second premolars with retained primary molars. A longitudinal radiographic study of 99 subjects from 12 years of age to adulthood. Eur J Orthod 2008;30:254-261.

4. Ith-Hansen K, Kjær I. Persistence of deciduous molars in subjects with agenesis of the second premolars. Eur J Orthod 2000;22:239-243.

5. Bodem O, Blumenshine S, Zeh D, Koch MJ. Direct pulp capping with mineral trioxide aggregate in a primary molar: A case report. Int J Paediatr Dent 2004;14:376-379.

6. Cordeiro MMR, Santos BZ, Reyes-Carmona JF, Figueiredo CP. Primary teeth show less protecting factors against root resorption. Int $\mathrm{J}$ Paediatr Dent 2011;21:361-368.

7. Ulusoy AT, Cehreli ZC. Regenerative endodontic treatment of necrotic primary molars with missing premolars: A case series. Pediatr Dent 2017;39:131134.

8. Schröder U. Pedodontic endodontics. In: Pediatric Dentistry: A Clinical Approach. In: Koch G. Copenhagen: Munksgaard; Wiley-Blackwell 2009:153165.

9. Fuks AB, Eidelman E, Pauker N. Root fillings with Endoflas in primary teeth: a retrospective study. J Clin
Pediatr Dent 2002;27:41-45.

10. Torabinejad M, Parirokh M. Mineral Trioxide Aggregate: A Comprehensive Literature Review-Part II: Leakage and Biocompatibility Investigations. J Endod 2010;36:190-202.

11. Torabinejad M, Parirokh M, Dummer PMH. Mineral trioxide aggregate and other bioactive endodontic cements: an updated overview - part II: other clinical applications and complications. Int Endod J 2018;51:284-317.

12. Akcay M, Sari S, Duruturk L, Gunhan O. Effects of sodium hypochlorite as disinfectant material previous to pulpotomies in primary teeth. Clin Oral Investig 2015;19:803-811.

13. Tunc E Sen, Bayrak S. Usage of white mineral trioxide aggregate in a non-vital primary molar with no permanent successor. Aust Dent J 2010;55:92-95.

14. Tomás-Catalá CJ, Collado-González M, GarcíaBernal D, et al. Biocompatibility of New Pulp-capping Materials NeoMTA Plus, MTA Repair HP, and Biodentine on Human Dental Pulp Stem Cells. J Endod 2018;44:126-132.

15. Quintana RM, Jardine AP, Grechi TR, et al. Bone tissue reaction, setting time, solubility, and $\mathrm{pH}$ of root repair materials. Clin Oral Investig. 2019;23(3):13591366.

16. Tang MH, Torabinejad M, Kettering JD. Leakage evaluation of root-end filling materials using endotoxin. J Endod 2002;28:5-7.

17. Barcelos R, Tannure PN, Gleiser R, Luiz RR, Primo LG. The influence of smear layer removal on primary tooth pulpectomy outcome: A 24-month, double-blind, randomized, and controlled clinical trial evaluation. Int J Paediatr Dent 2012;22:369-381.

18. Chandra A. Discuss the factors that affect the outcome of endodontic treatment. Aust Endod J 2009;35:98-107.

19. Siqueira JF, Rôças IN, Ricucci D, Hülsmann M. Causes and management of post-treatment apical periodontitis. Br Dent J 2014;216:305-312.

20. Bezgin T, Ozgul BM, Arikan V, Sari S. Root canal filling in primary molars without successors: Mineral trioxide aggregate versus gutta-percha/AH-Plus. Aust Endod J 2016;42:73-81. 